\title{
Handbike: Systematic review and prospective study
}

\author{
Handbike: Revisão sistemática e estudo prospectivo \\ Handbike: Revisión sistemática y estudio prospectivo
}

Received: 04/22/2021 | Reviewed: 04/30/2021 | Accept: 05/05/2021 | Published: 05/20/2021

Leonardo Silva Menezes

ORCID: https://orcid.org/0000-0003-1881-2309 Instituto Federal de Educação, Ciência e Tecnologia da Bahia, Brazil E-mail:leonardomenezes@ifba.edu.br

Antonio Carlos Peixoto Bitencourt

ORCID: https://orcid.org/0000-0003-1976-1187 Instituto Federal de Educação, Ciência e Tecnologia da Bahia, Brazil E-mail: antonio.carlos@ifba.edu.br

Antonio Gabriel Souza Almeida

ORCID: https://orcid.org/0000-0003-2955-6988 Instituto Federal de Educação, Ciência e Tecnologia da Bahia, Brazil E-mail: gabrielalmeida@ifba.edu.br

Luanda Kívia de Oliveira Rodrigues

ORCID: https://orcid.org/0000-0002-0801-2319 Instituto Federal de Educação, Ciência e Tecnologia da Bahia, Brazil E-mail: luandakivia@ifba.edu.br

\begin{abstract}
People with motor disabilities present diverse needs that the available products cannot fully addresses. Handbikes are human-powered vehicles that provide mechanical efficiency and can be used as a product for every day. The objective of this study is to understand how the design aspects of these vehicles have been investigated. As a methodology adopted, a systematic literature review was carried out, in order to find relevant scientific articles on the subject, and a prospective study, to verify the prospective scenario. For the selection criteria adopted, 21 scientific studies and 17 patents, none in Brazil, were found on the research platforms. These results demonstrate that there is potential to work with handbikes in the country due to the market gap.
\end{abstract}

Keywords: Handbike; Handcycle; Crank-propulsion; Motor disabilities.

\section{Resumo}

Pessoas com deficiência motora apresentam diversas necessidades que os produtos disponíveis não conseguem atender plenamente. As handbikes são veículos de propulsão humana que proporcionam maior eficiência mecânica e podem ser usados como um produto para o cotidiano. O objetivo desse estudo é entender como os aspectos para projetos desses veículos têm sido investigados. Como metodologia adotada, foram realizados uma revisão sistemática da literatura, a fim de encontrar artigos científicos relevantes sobre o tema, e um estudo prospectivo, para verificar o cenário prospectivo. Para os critérios de seleção adotados, foram encontrados 21 estudos científicos e 17 patentes, nenhuma no Brasil, nas plataformas de pesquisa. Esses resultados demonstram que há potencial para trabalhar com handbikes no país devido ao hiato no mercado.

Palavras-chave: Handbike; Handcycle; Propulsão por manivela; Deficiência motora.

\section{Resumen}

Las personas con discapacidades motoras presentan diversas necesidades que los productos disponibles no pueden satisfacer por completo. Las handbikes son vehículos propulsados por humanos que ofrecen una mayor eficiencia mecánica y pueden usarse como un producto para todos los días. El objetivo de este estudio es comprender cómo se han investigado los aspectos de diseño de estos vehículos. Como metodología adoptada, se realizó una revisión bibliográfica sistemática, con el fin de encontrar artículos científicos relevantes sobre el tema, y un estudio prospectivo, para verificar el escenario prospectivo. Para los criterios de selección adoptados, se encontraron 21 estudios científicos y 17 patentes, ninguna en Brasil, en las plataformas de investigación. Estos resultados demuestran que existe un potencial para trabajar con handbikes en el país debido a la brecha del mercado.

Palabras clave: Handbike; Handcycle; Propulsión de manivela; Discapacidades motoras. 


\section{Introduction}

In a world in which the relationships, the transactions and the exchange of information are largely based on the mobility of individuals, as well as the speed of their flow, people with disabilities face difficulties to follow or even to participate in these events. Society has been shaping forms of interpreting disability, which have become more prevalent, legitimizing the distinction of persons with disabilities. These conceptions are modes of thought built throughout history, not necessarily grounded in rational information and knowledge, which offer the elements used for the qualification of people with disabilities and the justifications for actions in relation to them (Carvalho-Freitas, 2007).

Trivial actions for many people, such as walking on the streets, going to school or working, represent barriers that make it difficult or even impossible for this portion of individuals to access them. As there is an interrelation between these activities, it turns out that people with disabilities have impaired mobility, so they are unable to raise their level of education (even being literate), and, consequently, failing to enter a competitive world of work. In addition to functional and autonomy losses, disability can bring problems of social discrimination and hinder the social insertion of people with disabilities (Carvalho-Freitas, 2009).

Individuals with motor disabilities can be of a neurologic or musculoskeletal nature. Among these disturbs caused by neurologic problems, it can be mentioned spine cord injuries related ones, as paraplegia and tetraplegia, and those caused by cranioencephalic injuries. Musculoskeletal conditions include lower and upper limb amputations, congenital diseases and some degenerative diseases as osteoporosis (Ortolan et al., 2001).

It is also important to differentiate paraplegia and tetraplegia. "Plegia" means absence of movement. Thus, paraplegia is the absence of movement in the limbs below the waist, whereas tetraplegia is the absence of movement in all four limbs. Conventional manual wheelchairs, used by most people with disabilities in the lower limbs (paraplegics, elderly people, etc.) due to the cost, have limited use since they demand a high physical effort from the users. This can cause injuries to the wrist, elbow and/or shoulder reducing their quality of life. Studies have shown that the mechanical efficiency of wheelchairs varies from 2 to $12 \%$ (Verellen et al., 2004).

Vehicles known as handbikes (handcycles), which are applied to sports and leisure to paraplegics, provide mechanical efficiency, since they are propelled by a crank system, and improve the user physiological responses. According to Verellen et al. (2004), the mechanical efficiency of these vehicles varies between 11 to $15 \%$. In contrast to conventional wheelchairs, handcycles perfectly serve the purpose of wheeling longer distances and overcoming inclinations without exerting enormous forces (Goosey-Tolfrey, 2010).

Thus, focusing on the relevance of the quantitative of individuals with motor disabilities (about 14 millions of people in Brazil, according IBGE 2010 Census) and their diverse needs - such as secure and confortable movement -, a handbike design that addresses these issues and provides a ride with better mechanical performance is essential. A product that aggregates all the characteristics raised tends to become a major provider of autonomy for people with motor disabilities, improving their quality of life and being an inclusion factor for them. The objective of this paper is to understand how all aspects relevant to the design of a handbike are being investigated. Specifically, it will be identified the important scientific contributions, as well as the patents to verify the prospecting scenario to study the development of a functional handbike.

\section{Methodology}

As handbikes are products, the research was conducted in two moments: first important scientific contributions were investigated in conventional search platforms, after that, patents in a patent search platform were verified. 


\subsection{Systematic review}

"A systematic literature review is a means of identifying, evaluating and interpreting all available research relevant to a particular research question, or topic area, or phenomenon of interest" (Kitchenham, 2004). "The systematic review consists in a specific scientific methodology that goes one step further than the simple overview" (Biolchini et al., 2005). "Systematic methods are used to avoid bias and to make possible a more objective analysis of the results, facilitating to make a conclusive synthesis about certain intervention" (Sampaio \& Mancini, 2007). "A systematic review addresses a specific question, utilizes explicit and transparent methods to perform a thorough literature search and critical appraisal of individual studies, and draws conclusions about what we currently know and do not know about a given question or topic" (Briner \& Denyer, 2012). These use a systematic and replicable method, explicitly and clear stated such that other researchers can repeat the process, or even update it. But these systematic methods never provide "answers" (Briner et al., 2009). Thus, a systematic review applies the same level of rigor to the research process that a well-conducted primary research would apply but depend on the quality of the primary data, being a summary of a set of studies. "A rigorous standalone literature review must be systematic in following a methodological approach, explicit in explaining the procedures by which it was conducted, comprehensive in its scope of including all relevant material, and, hence, reproducible by others who would follow the same approach in reviewing the topic" (Okoli, 2015).

To ensure the quality of the systematic review, it is necessary to establish phases with appropriate criteria and a review protocol. According to Kitchenham (2004), a systematic review must be conducted in discrete activities, summarized in three stages: Planning the Review, Conducting the Review and Reporting the Review. A pre-defined protocol (developed in the planning phase) is necessary to reduce the possibility researcher bias. Okoli (2015) proposed eight steps to be taken, necessary for a systematic literature review to be scientifically rigorous. Pedro (2019) classified these steps into: planning, selection, extraction and execution. Based on all of these classifications, the steps of the method used in the systematic review were defined and are presented in Figure 1.

Figure 1: Research method flow diagram for systematic review.

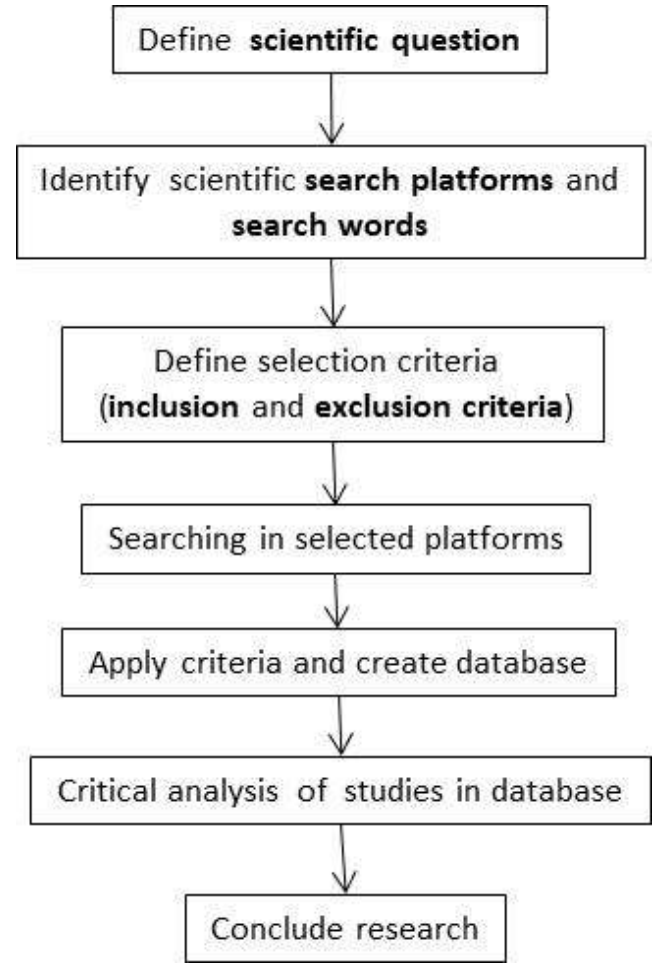

Source: Authors (2021). 
For the systematic literature review, it is necessary, first, a well-formulated, clear and answerable question. "The question guides the review by defining which studies will be included, what the search strategy to identify the relevant primary studies should be, and which data need to be extracted from each study" (Briner \& Denyer, 2012). The research problem question was: Has the development of functional human-powered crank-propulsion vehicles for people with motor disabilities been studied?

Afterward, the relevant scientific search platforms were identified. For the search for academic articles were used ScienceDirect and Google Scholar. ScienceDirect is a full-text scientific database of journals and books, provided by the medical and scientific publishing company Elsevier (Tober, 2011). Google Scholar is a search tool for academic articles that are available on web repositories, academic publishers, professional societies, universities or academic sites, such as articles from congresses, books, theses and dissertations, as well as articles from open or paid access journals, in multiple languages (Caregnato, 2012; Tober, 2011).

"The inclusion and exclusion criteria need to be applied to each paper and study found to determine whether the paper is relevant to the review" (Briner \& Denyer, 2012). The search words were properly determined in order to survey the data. Since there are different terms to name these vehicles and different ways for writing them, each one was included as a search word: "handbike", "handcycle", "hand bike", "hand cycle", hand-bike", "hand-cycle". Due to their characteristics, handbikes are of medical and sporting interest. So, as inclusion criteria, articles about a relevant topic to be considered in the design of a handbike were included in the database. The articles found and classified as Medical (when only physiology or medical issues were discussed), Sports (when only issues of sports performance were discussed), Repeated, Non-available or Others (when the subject does not meet any of the established criteria) was counted, but did not go to the next stage. No language criterion was established. As exclusion criteria, editorial articles, letters or newspapers were discarded. Only articles published from January 2000 to December 2020 were counted. The search was carried out in an advanced form and was conducted in $14 / 03 / 2021$.

According to Briner and Denyer (2012), "a key part of systematic review is that each study is critically appraised in relation to the quality criteria devised". Finally, once all the studies have been collated and appraises, the next stage is analysis and synthesis. Then, the most important data of each study were recorded and summarized.

\subsection{Prospective study}

A prospecting research is centered on technological changes, in changes in of functional capacity or in the time and meaning of an innovation (Dos Santos Amparo et al., 2014). It is a systematic means of mapping future scientific and technological developments capable of building in a way, an industry, the economy or society as a whole (Mayerhoff, 2008). In the field of Science, Technology and Innovation, technological prospecting studies are considered fundamental to promote the ability to organize innovation systems, which respond to the interests of society (Ribeiro \& Alves, 2020). A prospective study aims to incorporate the technology already developed in order to understand market trends to develop new industrial applications. These are conducted in order to add value to the information in the present, transforming it into knowledge (Santos et al., 2004). According Ribeiro \& Alves (2020), these studies also provide more specific information, such as relevant technologies, possible partners or competitors, innovations and movements of competitors in national and international markets.

According to Bahruth et al. (2006 apud Mayerhoff, 2008), these studies constitute four distinct phases: preparatory phase (defining objectives, scope and methodology); pre-prospective phase (details of the methodology and survey of the data source); prospective phase (data collection, treatment and analysis); and post-prospective phase (communication of results, implementation of actions and monitoring). Based on of this classification, the steps of the method used in the prospective 
study were defined and are presented in Figure 2.

Figure 2: Research method flow diagram for prospective study.

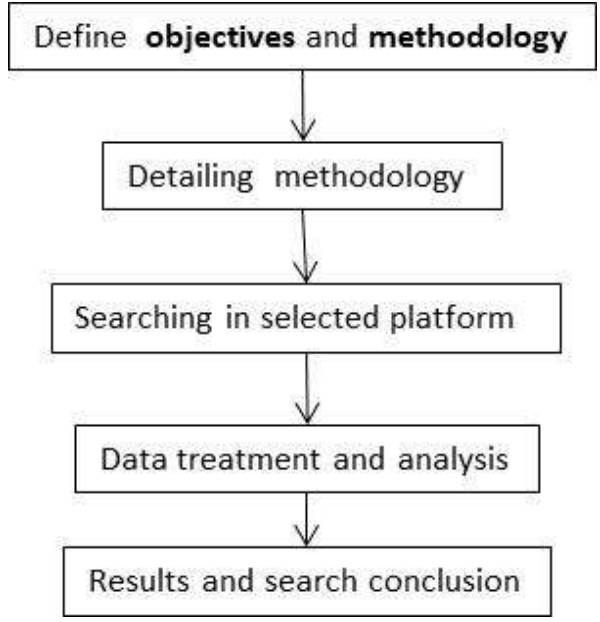

Source: Authors (2021).

Following these steps, the objective of the prospective study was verifying patents for handbike systems or subsystems to observe products that have contributed to the development of these vehicles.

For the search for patents, Espacenet was used. It is an online platform with free access that allows searching millions of patents from 1782, with bibliographic information, and that is often used in other free and private search systems (Pires et al., 2020).

Again, the search words used were: "handbike", "handcycle", "hand bike", "hand cycle", hand-bike", "hand-cycle". The query has been made in advanced search in the title or in the abstract. No language criterion was established. For a better understanding of the prospective scenario, the countries where the patents were submitted, the date of its publication and the applicants were filtered.

The product technology can be treated as solution for a specific system or subsystem. These groups are classified into codes such as the International Patent Classification (IPC). This classification is an international system adopted to group the patents to facilitate the search and technology evaluation (INPI, 2020). This classification "has as its primary purpose the establishment of an effective search tool for the retrieval of patent documents by intellectual property offices and other users, in order to establish the novelty and evaluate the inventive step or non-obviousness (including the assessment of technical advance and useful results or utility) of technical disclosures in patent applications" (WIPO, 2020). Therefore, the code IPC subgroup must be filtered.

Since handbikes are human-powered vehicles, they are best classified in the class of IPC B62 (Land vehicles for travelling otherwise than on trails). However, there are some possibilities to subclass, group and subgroup: subclass B62K, cycle propulsion vehicles, and subclass B62M, which include Rider propulsion of wheeled vehicles. Then, handbike can be associated to the following main groups of IPC classification: B62K 5/00 (Cycles with handlebars, equipped with three or more main road wheels) and B62M 3/00, (Construction of cranks operated by hand or foot). Finally, the subgroups of IPC classification that can represent handbikes are B62K 5/023 (Tricycles specially adapted for disabled riders, e.g. personal mobility type vehicles with three wheels), B62M 1/14 (Rider propulsion of wheeled vehicles operated exclusively by hand power), B62M 1/36 (Rider propulsion of wheeled vehicles with rotary cranks) and B62M 3/14 (Hand-grips for hand-operated crank). Therefore, these IPC subgroups were filtered.

The query was conducted in 14/03/2021 and then the data obtained in Excel were processed. Once all the patents have 
been collated, the next stage is data treatment and analysis of results.

\section{Results and Discussion}

\subsection{Systematic review}

Figure 3 shows the articles found arranged by search word and by search platform. The results for the terms "hand bike" and "hand-bike", as well as for the terms "hand cycle" and "hand-cycle" were the same and counted together. It is possible to notice that the term "handbike" was the most used in scientific production (57 articles) and the terms "hand bike/ hand-bike", the least (11 articles). The terms "handcycle" and "hand cycle/ hand-cycle" presented almost similar quantities, respectively, 28 and 30 articles.

Figure 3: Results for the search for academic studies.

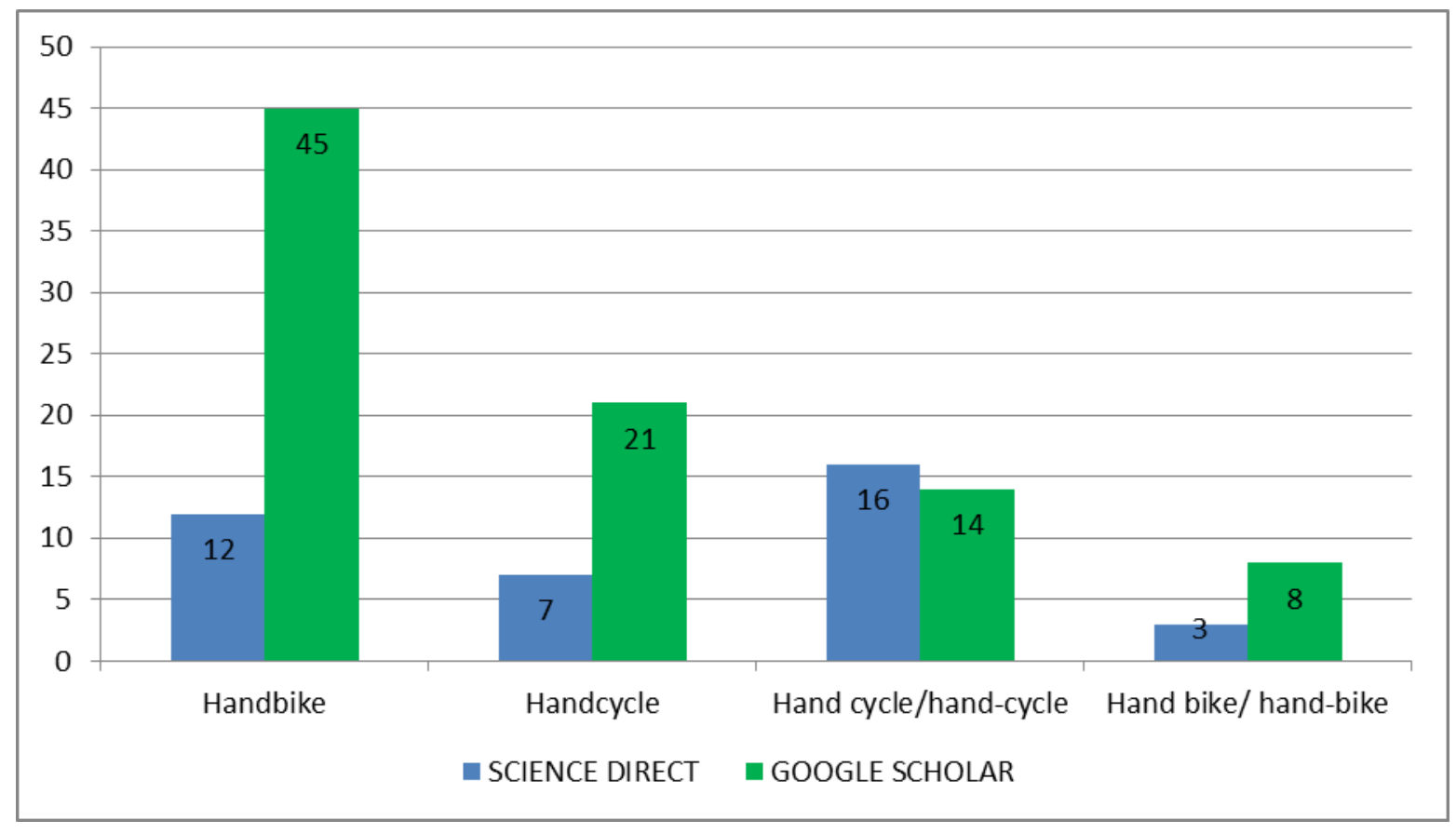

Source: Search data (2021).

The amount of results found in ScienceDirect has always been smaller than in Google Scholar, except for the term "hand cycle", which was also the largest among the search words found in the platform.

About the results obtained in ScienceDirect, 8 articles (21\% of those found on the platform and $38 \%$ of the total) were relevant after application of the selection criteria, about $63 \%$ related to the search word "handbike". The number of studies not related to the search words - articles presented as a result on platform, but related to another theme -, 37\% of those found on the platform, was considerable, since all searches were carried out in an advanced search. Most of them were related to the search words "hand cycle/ hand-cycle", which is representative to determine the best term for naming the vehicle.

About the results obtained in Google Scholar, 13 articles (15\% of those found on the platform and $62 \%$ of the total) were relevant after application of the selection criteria, about 54\% related to the search word "handbike" and $31 \%$ related to the search word "handcycle". For this platform, the number of articles related only to medical use of handbikes was considerable; about $30 \%$ of those found on the platform. The number of results found in search on this platform but not available to read also was considerable: about $23 \%$ of those found on the platform and $95 \%$ of the total. This is a representative number, since is 
similar to the number of studies considered as relevant after application of the selection criteria.

Figure 4 summarizes the result found in the systematic review after applying the selection criteria on the search results.

Figure 4: Results for the systematic review.

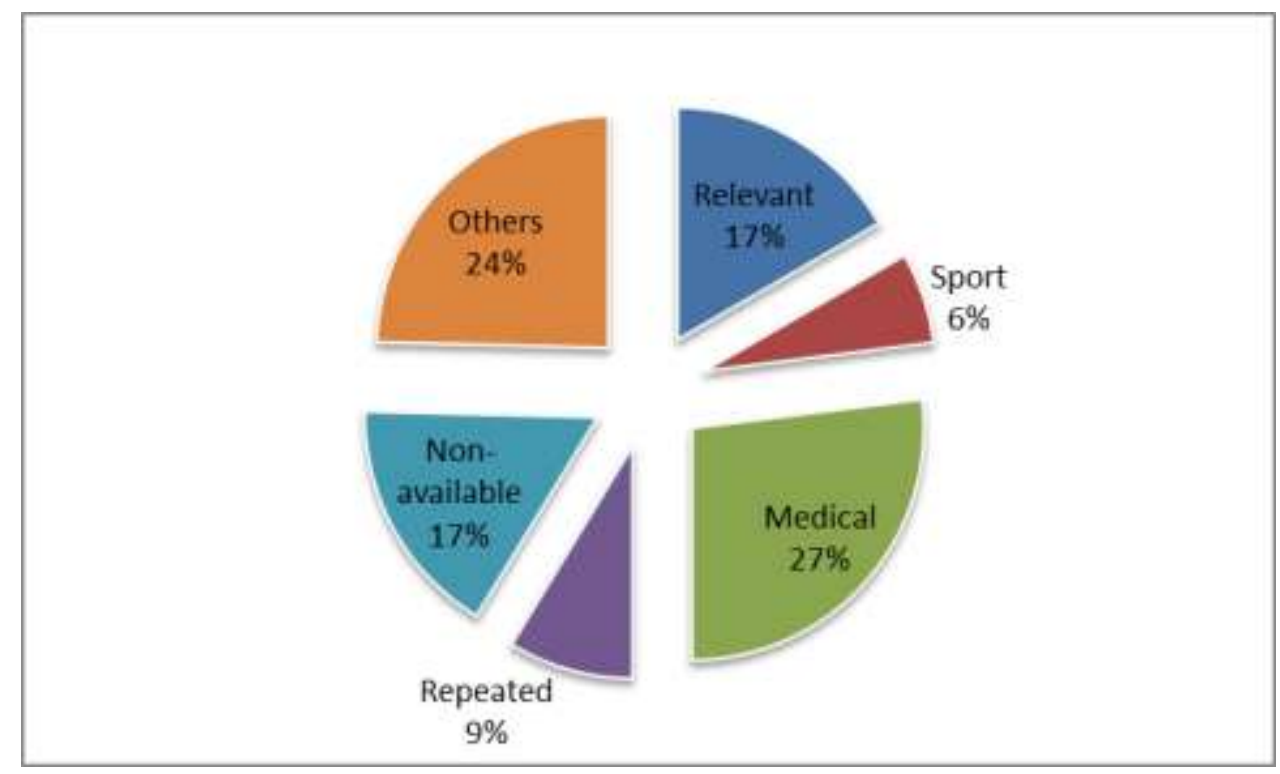

Source: Search data (2021).

So, $33 \%$ of the studies found corresponded only to sport or medical research (for improvements in performance or health) and had no contribution to the handbike design. Another $24 \%$ did not match the terms searched and $17 \%$ were not accessible for reading. There were also repeated articles on the search platforms, letters or newspaper articles. Thus, 126 results were found and only 21 studies met the established criteria. Table 1 presents these studies, the search word and the search platform used to find them (where SD is ScienceDirect and GS is Google Scholar), and their main contribution to handbike design.

For a better analysis of each of the studies found, they were grouped into:

a) Biomechanics and kinematics considerations for handbike design and;

b) Components analysis and concepts of handbikes. 
Table 1: Results for the systematic review in search platforms.

\begin{tabular}{|l|c|l|}
\hline \multicolumn{1}{|c|}{ Study } & Search word & \multicolumn{1}{|c|}{ Contribution } \\
\hline Faupin et al., 2006 & handbike/SD & $\begin{array}{l}\text { Kinematic parameter analysis, effect on joints, effect } \\
\text { on speed ratio joints }\end{array}$ \\
\hline Faupin \& Gorce, 2008 & handbike/SD & $\begin{array}{l}\text { Kinematic parameter analysis effect on joints and } \\
\text { crank positioning }\end{array}$ \\
\hline van der Woude et al., 2008 & hand bike/SD & Crank types and configurations, references. \\
\hline Verellen et al., 2008 & hand cycle/GS & Torque distribution pattern \\
\hline Hettinga et al., 2010 & hand cycle/SD & $\begin{array}{l}\text { Handbike configurations, crank types and } \\
\text { configurations }\end{array}$ \\
\hline Kyncl, 2011 & handbike/GS & Concept of off-road handbike \\
\hline van Drongelen et al., 2011 & handbike/SD & Propulsion kinetics data \\
\hline Arnet et al., 2012 & handbike/SD & Shoulder joint motions investigation \\
\hline Arnet, van Drongelen, et al., & handbike/SD & $\begin{array}{l}\text { Effectiveness of the force applied under different } \\
\text { conditions of speed and inclination }\end{array}$ \\
\hline 2012 & handcycle/GS & $\begin{array}{l}\text { Comparison of biomechanical aspects of handbikes } \\
\text { and wheelchairs }\end{array}$ \\
\hline Vaghetti et al., 2012 & handbike/GS & Concept of off-road handbike \\
\hline Hrdlicka, 2015 & handcycle/GS & Concept of recreational handbike \\
\hline Jeang et al., 2015 & handcycle/SD & Design parameters of handbikes \\
\hline Litzenberger et al., 2015 & handbike/GS & Concept of a lever-powered handbike \\
\hline Diniz \& Ferro, 2016 & hand bike/GS & $\begin{array}{l}\text { Handbike configurations, crank types and } \\
\text { configurations }\end{array}$ \\
\hline Kim et al., 2016 & handbike/GS & Concept of a handbike for leisure activities \\
\hline Matvijová, 2017 & handbike/GS & Concept of low cost handbike \\
\hline Leal \& Silva, 2018 & $\begin{array}{l}\text { Design of a human powered speed record handcycle, } \\
\text { selection of transmission }\end{array}$ \\
\hline Maries, 2019 & Design of handbike transmission \\
\hline Moreno, 2019 & $\begin{array}{l}\text { Summary of the biomechanical, kinematic and kinetic } \\
\text { considerations for handbike design }\end{array}$ \\
\hline Stone, 2019 & Concept base on anthropometric data \\
\hline Himarosa \& Sunardi, 2020 & handGs & \\
\hline
\end{tabular}

Source: Search data (2021).

\subsubsection{Biomechanics and kinematics considerations for handbike design}

In their article, Faupin et al. (2006) studied handbike propulsion in maximal sprint conditions in order to determine potential risk factors for joint pain. They compared three different gear ratios (22/21 versus 32/ 21 and 44/21) and conclude that the highest gear ratio helped the user to obtain a higher maximal velocity during a sprint while reducing the frequency of movements, but also impacting on some angular parameters, such as the trunk flexion/extension range of motion and the shoulder adduction/abduction range of motion. According to the authors, although handbikes are considered more efficient and less constraining than the hand-rim wheelchairs, in submaximal propulsion, the maximal angular amplitudes of the upper extremities joints during handbike propulsion found in their study are near from the values obtained with a hand-rim wheelchair. I.e., "they might be considered as risk factors, for shoulder tendonitis as well as for Carpal Tunnels Syndrome" (Faupin et al., 2006) in submaximal propulsion. In another article, Faupin and Gorce (2008) carried out a kinematic simulation 
of handcycling propulsion, adjusting crank axis height in relation with the user's shoulder level, in order to investigate some specific ergonomic aspects to minimize the joint range of upper extremity motions and/or avoid reaching the joint limit. This study, considered by the authors as a first step, observed some trends to reduce shoulder and wrist joint range of motion moving crank position. They theorized that some considerations for handbike parameters, such as the crank width approximately the same as the shoulder and the distance between the crank and the shoulders not allowing complete elbow extension. This influence others parameters related to handbike configuration, such as the backrest angle and the distance of the seat compared to the cranks. "This work could consequently have industrial repercussions on vehicle design for motor disabled user" (Faupin \& Gorce, 2008).

Another study investigated shoulder joint motions in handbike propulsion: Arnet et al. (2012). The authors aimed to quantify glenohumeral contact forces (the mechanical load on the shoulder) and muscle forces during handbike propulsion, and compare them to previous results of handrim wheelchair propulsion. They measured power and external force applied to the crank and compared to previous studies in hand-rim wheelchair propulsion, concluding the least load forces during handbike propulsion. "Therefore, based on this study, the handbike can be recommended as means of transportation for longer distances outdoor or as a training device (...)" (Arnet et al., 2012).

Hettinga et al (2010) describe an overview of the hand biking advantages, handbike history (although the reference used is questionable), system and subsystems features and configuration, such as gear ratio and crank length, biomechanics discussion. The authors consider the handbike as a means of daily transportation for people with lower-limb impairment due to high gross mechanical efficiency of the hand cycling, which, according to them, may be almost twice as high as that in the wheelchair hand-rim propulsion. In their study, they present a handbike classification scheme, comparing the arm-powered and arm-trunk-powered types and discuss their effects on performance. Another interesting contribution in this article is a flowchart that summarizes the ergonomics of the factors that affect performance and the subsequent constituents of the performance of hand-cycle-user combination, showing the complexity of performance-influencing factors within a combined physiologic and biomechanical framework of hand cycling performance in daily life. Although they still consider little the number of biomechanical studies, the authors summarize the information published about these studies, discussing them, contributing to the understanding of the mechanism and to the best selection of solutions in the handbike development.

Litzenberger et al. (2015) investigate different design parameters of handbikes (crank lengths, crank positions and backrest positions) examining elite athlete familiar with handcycling. The athlete pedaled at $130 \mathrm{~W}, 160 \mathrm{~W}$ and $190 \mathrm{~W}$ power levels, varying seating position (position normally used and a $5 \mathrm{~cm}$ elevated backrest), crank height (from 1: lowest to 4 : highest) and crank length $(160 \mathrm{~mm}, 165 \mathrm{~mm}$ and $175 \mathrm{~mm}$ ). "It could be shown, that muscular effort is clearly influenced by the handcycle parameters investigated and that these measurements can be used to individually optimize the position in a handcycle with regard to muscular effort" (Litzenberger et al., 2015).

Verellen et al. (2008) investigate the consistency of the within-cycle torque pattern in handcycling. Crank position and torque were recorded by a cycle ergometer system every minute during the test, being converted to relative values to the peak torque value within each cycle. The transmission from motor to cranks had a gear ratio of 0.59 . The results showed torque distribution pattern relatively constant. "The results of this investigation suggest that a consistent within-cycle torque distribution pattern exists that is minimally influenced by power output and fatigue" (Verellen et al., 2008). This pattern can be divided into quadrants based on crank position to understand the influence of handbike configuration and improve mechanical efficiency.

So, van Drongelen et al. (2011) developed an instrumented handbike system to measure (in three dimensional measurement) the forces applied to the handgrip during handbiking and analyzing them in detail. The crank used in the investigation was length of $0.17 \mathrm{~m}$ and the outside distance between the handgrips was $0.44 \mathrm{~m}$. The results presented the 
applied force in handgrip expressed in crank coordinate system, showing that most force was produced in the pulling phase. According to the authors, this fact was likely occurred due to the use of the thorax during pulling in contrast to during pushing. "Further the weight of the arm will contribute to force production in the downward phase whereas in the upward phase the weight of the arm has to be compensated by muscle force" (van Drongelen et al., 2011). These characteristics determinate the different crank types and configurations. This will be better discussed in Arnet, van Drongelen, et al. (2012) study, which purposed to investigate the influence of the exercise condition on the force characteristics of synchronous handcycling. The crank used in the investigation also was length of $0.17 \mathrm{~m}$ and the outside distance between the handgrips was $0.44 \mathrm{~m}$. They conclude that, at equal power output and with a fixed gear setting, speed had an influence on the force characteristics of handbike propulsion. However, there was no difference in the force characteristics between propelling on an incline or at ground level with the same speed in test conditions.

Van de Woude et al (2008) evaluate external power output and physiological responses of synchronous and asynchronous hand cycling at submaximal and peak levels of activity. Their results have presented a gross mechanical efficiency and a peak performance lead higher for synchronous hand cycling. However, no significant differences were found between the configurations for physiological responses. Those results are important to understand which configuration delivers best responses to vehicle propulsion with least efforts to riders.

The article of Kim et al (2016) provides basic data for the development of a handbike. The authors present a comparative study in which rotation tests of upper limbs at different angles of backrest and handle were performed to measure the applied force. These different angles determine different distances between the handbike crank and the user trunk, interfering with applied force. The tests were performed on individuals without articulations impairment or any other problem related to articulations. However, due to the equipment used in the experiments, the results presented were only for the user right hands, so they represent a partial value of the total force.

Vaghetti et al. (2012) presented a study that relates biomechanical aspects of handbikes and wheelchairs, through the observation of some Brazilian handbike users, in a descriptive research, and through a survey questionnaire. The authors noticed that the handbikes were handmade developed, rustic and with adapted pieces, without any ergonomic or biomechanical study, resulting in dimensional differences in all vehicles. Some qualitative aspects observed were the greater speed of hand bikes compared to wheelchairs, allowing for greater daily commuting, but their lesser possibility of access to indoor environments.

Stone (2019) presented a study that summarizes the biomechanical, kinematic and kinetic considerations for handbike design in a detailed literature review. The author investigated biomechanical and physiological parameters to provide an understanding of elite recumbent handcycling, including effects of crank position, crank length, handgrip width and optimal cadence with focus on optimizing the configuration of the recumbent handbike. Although the thesis presents clear focus on recumbent handbike, the summary data is an important source of information for the development of any type of handbike.

\subsubsection{Components analysis and concepts of handbikes}

Kyncl (2011) and Hrdlicka (2015) presented in each their studies concepts of off-road handbike. Kyncl (2011) designed some chassis parts, such as wheels and tires (size and number), and the concepts of traction and steering, frame, suspension and brake system. Some structural calculations was developed, however the concept was universal, i.e., it was not according any regulation. Hrdlicka (2015) presented a project in which components and parts were evaluated based on requirements obtained by market research. The concept was developed observing ergonomics, using axle transmission, with traction on the two front wheels and with the possibility of using an auxiliary electric motor. Analysis was carried out on 
structural components and computer model simulations. The project resulted in a vehicle weighing around $22 \mathrm{~kg}$ without an auxiliary drive.

Jeang et al. (2015) and Matvijová (2017) presented in each their studies concepts of recreational handbike. Jeang et al. (2015) presented a concept of handbike developed from a product development process. First, they applied Quality Function Deployment (QFD) technique to clarify customer requirements, conducting a product-usage survey. Then, customer needs were converted into technical quality requirements. So, three conceptual models were evaluated and one was chosen to follow the phase. Computer-aided safety simulation analysis in the structure was performed and standard regulatory tests and road tests were done on the final prototype. "Further amendments were later made by equipping the handcycle with electric-assist control technology to finalize the design of an 'electric-assisted handcycle' suitable for long distance use" (Jeang et al., 2015). Matvijová (2017) designed a handbike for leisure activities. The components and parts were evaluated based on requirements obtained by market research. Two concepts were proposed: one with a detachable fork and one with a folding frame. Both concepts were developed with two wheels at the rear and one at the front. To obtain more stability, camber was evaluated in the rear wheels. Analysis was carried out on structural components and computer model simulations.

Diniz \& Ferro (2016) presented a concept of a lever-powered handbike. In opposite to cranck-powered handbikes, in their concept, developed with two wheels at the front and one at the rear, the user pulls and pushes a lever attached to a gear, which moves the rear wheel. According to the authors, the preliminary tests indicated a positive perception of the use of the prototype, however some adjustments would be necessary.

Leal and Silva (2018) presented a concept of low cost handbike. According to the authors, as there were no standards or regulations for handbikes design, it was necessary to consult the technical standards used in conventional bicycles and wheelchairs. The concept was developed observing the ergonomics. Structural analysis was performed to maintain the focus on stability and safety. After prototype tests, new needs were found, such as a parking brake and a steering lock, for the user get in and out. "The project prioritizes simplicity in construction and maintenance, proposing changes in existing concepts, resulting in a reduction of final cost, contributing to the popularization of this sport practice in leisure, and helping in the inclusion of this portion of society" (Leal \& Silva, 2018).

Maries (2019) presented a design of a human powered speed record handbike. The author carried out a review study of biomechanics and identified the personal athletes' requisites, since it was a customized design. The design was focused on performance, so aerodynamics and performance simulations were performed to express maximum power and high speed. Product development included defining the steering geometry and calculating and selecting the transmission.

Himarosa and Sunardi (2020) developed a prototype designed based on Indonesian anthropometric data. Then, they performed a frame design and finite element analysis studies. The final concept was equipped with an adjustable chair to adjust the user distance to the crank. The manufactured prototype can be used by riders' weight to $160 \mathrm{~kg}$.

Moreno (2019) presented a design of handbike transmission. A market study was carried out and the main problems of wheelchairs users were analyzed to be considered in project. Each transmission component was selected, from crank to chainwheel, calculating their requirements from input considered data (forces, weight and dimensions).

\subsection{Prospective study}

After searching, 51 patents applications were found and presented in Fig. 4 by search word. 
Figure 4: Results for patents applications by search word.

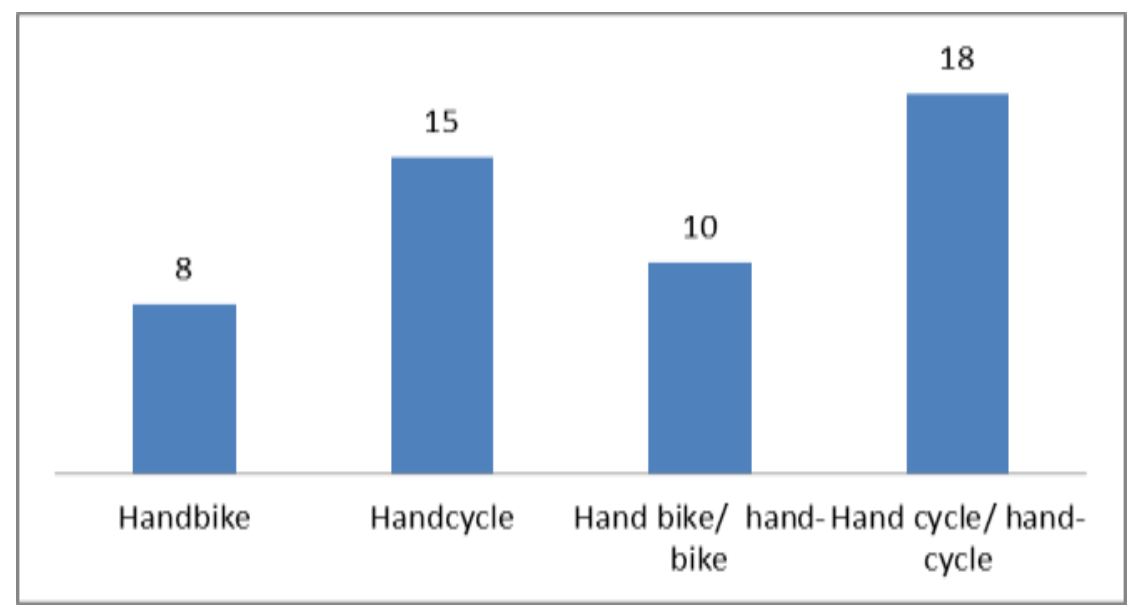

Source: Authors with Espacenet (2021).

Again, the results for the terms "hand bike" and "hand-bike", as well as for the terms "hand cycle" and "hand-cycle" were the same and counted together. 18 applications were found for the term "hand cycle / hand-cycle", which was the search word that presented the most results. There were 15 results for the term "handcycle", 10 for the term "hand bike/ hand-bike" and 8 for the term "handbike".

Only 17 patents ( 1 repeated) were found in the searched subgroups of IPC classification, some were classified in more than one subgroup. Then, the search found:

- 2 for B62K 5/023 (Tricycles specially adapted for disabled riders, e.g. personal mobility type vehicles with three wheels);

- 15 for B62M 1/14 (Rider propulsion of wheeled vehicles operated exclusively by hand power);

- 3 for B62M 1/36 (Rider propulsion of wheeled vehicles with rotary cranks) and

- 1 for B62M 3/14 (Hand-grips for hand-operated crank).

Thus, about $71 \%$ of the applications found on the platform were classified as a system or a subsystem for a handpowered vehicle operated by a rider. Only 3 patents were classified as a system or a subsystem for a crank-powered vehicle operated by a rider, 2 as an adapted tricycle for disabled riders, and 1was classified as a system or a subsystem for handoperated crank.

The patents with the search word "handcycle" were the most often, representing $61 \%$ of the applications. The Table 2 presents these results by country where the patent was applied for.

Table 2: Patents in searched IPC subgroup classification by country.

\begin{tabular}{|l|c|c|c|c|c|}
\hline Country Term & Handbike & Handcycle & $\begin{array}{l}\text { Hand bike/ } \\
\text { hand-bike }\end{array}$ & $\begin{array}{c}\text { Hand cycle/ } \\
\text { hand-cycle }\end{array}$ & $\begin{array}{c}\text { Total by } \\
\text { Country }\end{array}$ \\
\hline United States & - & 8 & - & - & $\mathbf{8}$ \\
\hline South Korea & - & 2 & 1 & 1 & $\mathbf{4}$ \\
\hline Germany & 2 & - & - & - & $\mathbf{2}$ \\
\hline Japan & - & - & - & 2 & $\mathbf{2}$ \\
\hline Australia & - & 1 & - & - & $\mathbf{1}$ \\
\hline \multicolumn{1}{r|}{ Total } & $\mathbf{2}$ & $\mathbf{1 1}$ & $\mathbf{1}$ & $\mathbf{3}$ & $\mathbf{1 7}$ \\
\hline
\end{tabular}

Source: Search data (2021). 
The patents were applied in 5 countries: 8 in the United States (all for the term "handcycle"); followed by South Korea, with 5 applications; Germany and Japan, 2 applications; and 1patent was applied in Australia . There are no patents applied in Brazil with any term. Here it is interesting to note that both countries where English is the official language, the term most often was "handcycle", while in the others countries there were a dispersion, as in South Korea.

Table 3 presents the results for the prospective study. Most of the results have been applied in the past 20 years, so, unless by some consideration, they should be in active status.

Some applicants found in the search are companies, such as Lasher Sport LLC and Motorwel Co LTD, and universities, such as Brigham Young University and Yonsei University.

Table 3: Results for the prospective study.

\begin{tabular}{|c|c|c|}
\hline Patent & IPC & Search word \\
\hline Franks \& Tim, 1997 & B62M1/14 & Handcycle \\
\hline Lee, 1998 & B62M1/14 & Handcycle \\
\hline Rotz et al., 2001 & B62M1/14 & Handcycle \\
\hline Peterson, 2002 & B62M1/14 & Handcycle \\
\hline Jin-Man, 2007 & B62M1/14 & Handcycle \\
\hline Sato, 2010 & B62M1/14 & Hand cycle \\
\hline Bailey \& Hoepnner, 2011 & B62M1/14 & Handcycle \\
\hline Lasher, 2012 & B62M1/14 & Handcycle \\
\hline Lasher, 2013 & B62M1/14 & Handcycle \\
\hline Sato, 2013 & B62M1/14 & Hand cycle \\
\hline Dong-Woo \& Yon-Seung, 2014 & B62M1/36 & Hand bike \\
\hline Lofgren \& Stewart, 2014 & B62M1/14 & Handcycle \\
\hline van Galen, 2014 & B62K5/023 & Handcycle \\
\hline Kraiss, 2016 & B62M1/36 & Handbike \\
\hline Jong- Bae et al., 2016 & B62M1/14 & \multirow{2}{*}{ Hand cycle } \\
\hline Jin-Sung et al., 2016 & B62M3/14 & \\
& B62K5/023 & Handcycle \\
\hline Kirschke \& Fiedler, 2019 & B62M1/14 & B62M1/36 \\
\hline & B62M1/14 & Handbike \\
\hline
\end{tabular}

Source: Search data (2021).

Franks and Tim (1997), Lee (1998), Rotz et al. (2001) and Sato (2010) created different concepts of handbikes. Franks and Tim (1997) developed a handbike that has a frame with a front steerable wheel and an attitude control system (a mechanism that is adjusted so that the seat and forward frame can be properly center upright in relation to the rear wheels of the vehicle). Lee (1998) developed a modified prone handbike that has a frame including a rear axle and a central support rod to support a rider and a front fork assembly, where a front wheel and a pedal assembly are mounted. Sato (2010) created a twowheel handbike with front-wheel drive. According to the author, this vehicle can be easier to handle when entering a narrow place or on a gentle uphill. These three patents have already expired. Rotz et al. (2001) developed a handbike that has an articulated frame and configured so that the handcycle is steerable by pivoting of the front and rear portions relative to each other. This patent has been abandoned. Figure 5 presents the drawings of these inventions. 
Figure 5: Drawings of patent US6105986A, US6036210A, US2002030342A1, and JP2012071728A, respectively.
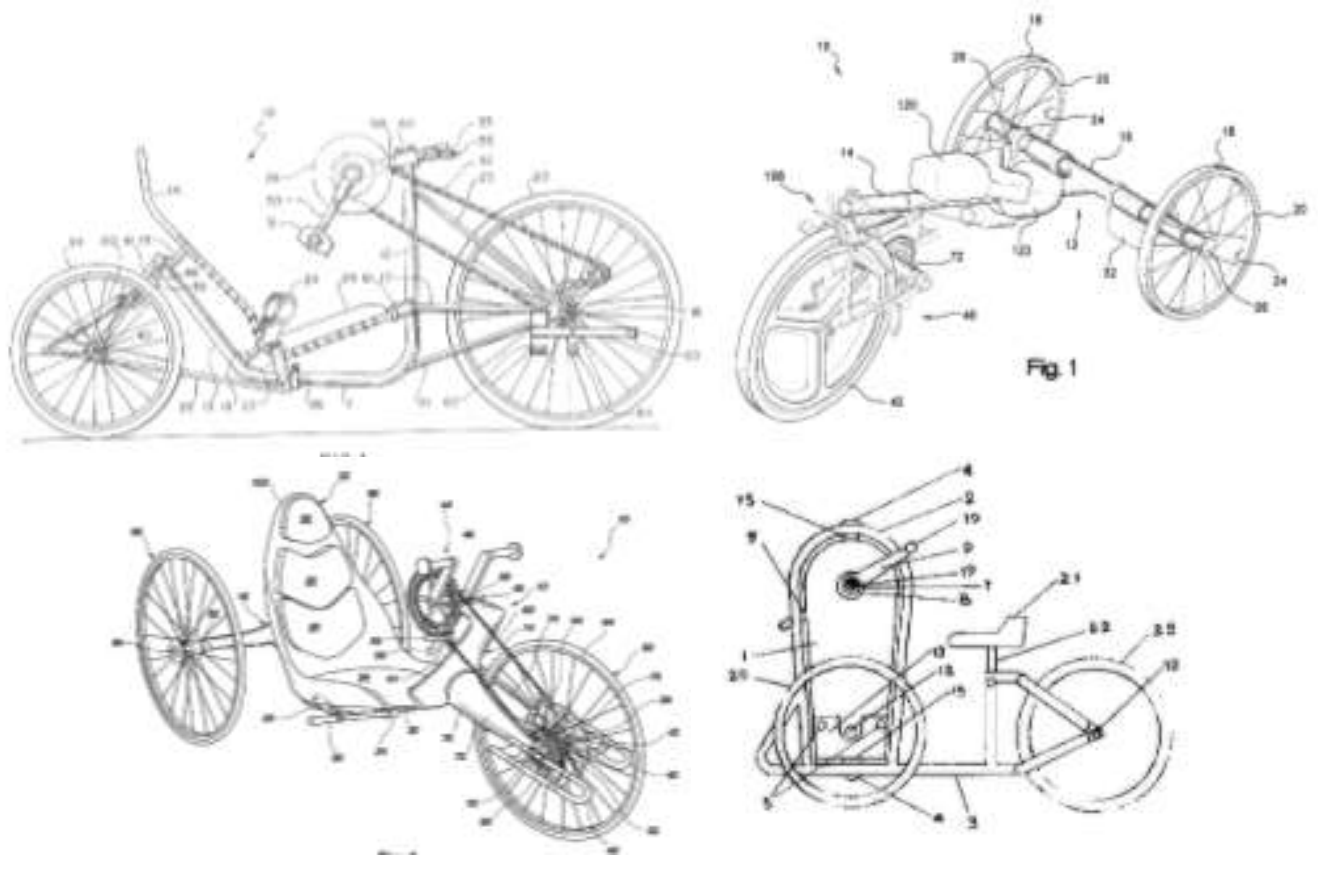

Source: Franks (1997), Lee (1998), Rotz et al. (2001), Sato (2010).

Peterson (2002) created an extendable hand pedals assemble for handbikes that comprises a bar containing a handle that can be adjusted in length, positioning it within the crank arm. Fig. 6 presents a drawing of the invention. This patent has been abandoned.

Figure 6: Drawing of patent US2003075002A1.

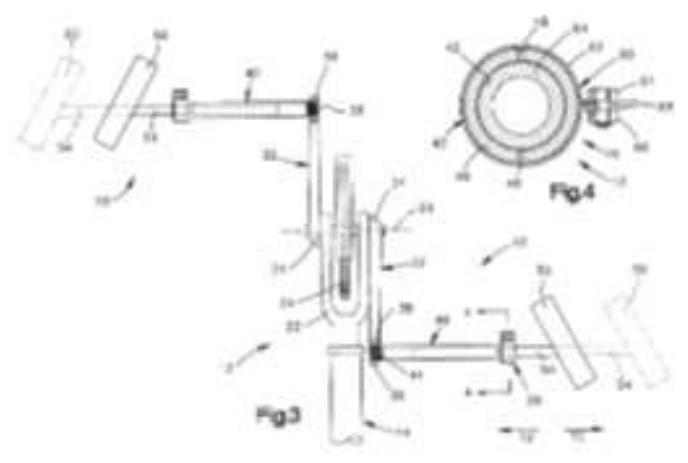

Source: Peterson (2002).

Jin-Man (2007) designed a hand-held bicycle kit for a wheelchair that comprises a front fork assembly, where a front wheel and a crank assembly are mounted. This kit is easily attachable to a wheelchair transforming it in a handbike. Figure 7 presents a drawing of the invention. This patent is active. 
Figure 7: Drawing of patent KR100886325B1.

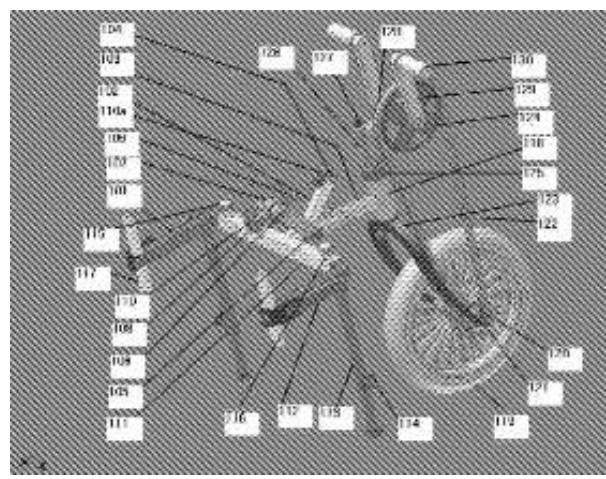

Source: Jin-Man (2007).

Bailey and Hoepnner (2011) identified that the main drive sprocket (crank assembly) is positioned in front of the rider's face on a handbike. Thus, it is not only an obstacle for the user when mounting the handbike, but also a potential safety hazard in the event of an accident. Then, they created a rotating mechanism for hand bikes (crank assembly). Fig. 8 presents some drawings of the invention. This patent has been abandoned.

Figure 8: Drawing of patent US2012235377A1.
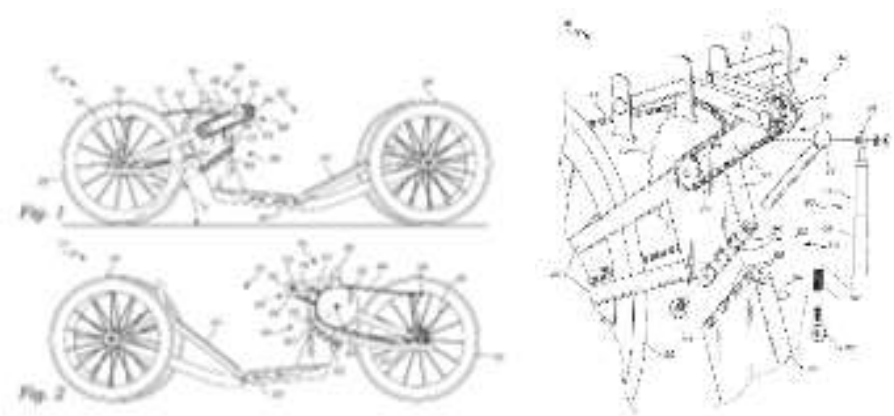

Source: Bailey and Hoepnner (2011).

Lasher $(2012,2013)$ observed some undesirable considerations on handbikes. He noted that when a rider get in to a handbike from a wheelchair, he uses some moving parts, such handlebar, which can turn or rotate, moving the fork or the vehicle, causing the rider to lose of his balance. Thus, he developed a stabilizing device for a handcycle that locks these parts. He also noticed that the shock of front wheel hitting a bump is felt by the rider, causing undesirable motion or vibration in the handlebars. Then, he proposed a suspension for handbikes. These two patents have already expired.

Sato (2013) created a ratchet-type handike to correct a mechanism invented and applied in the past by him, which would be impossible to manage. The patent has already expired.

Dong-Woo and Yon-Seung (2014) developed a vehicle that can be a recumbent bike or a handbike, depending on the position of the driving unit, as presented in Figure 9. This patent is active. 
Figure 9: Drawings of patent KR101693815B1.
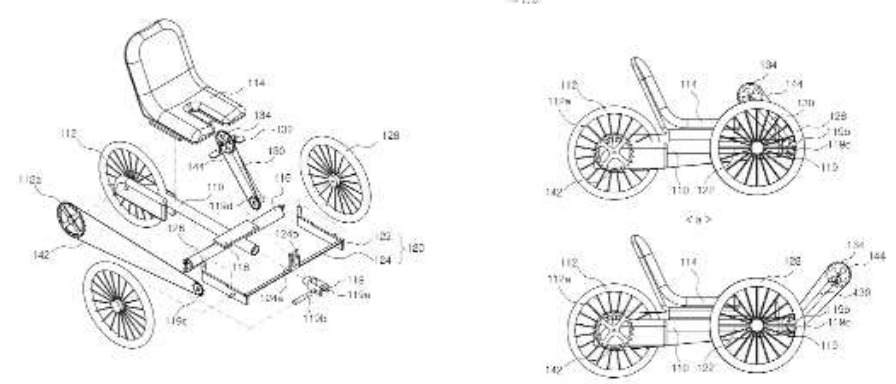

Source: Dong-Woo and Yon-Seung (2014).

Lofgren and Stewart (2014) developed an arm-actuated brake system. The mechanism comprises a lever operated by the movement of the rider's wrist and/or forearm, as shown in Figure 10. This patent has been abandoned.

Figure 10: Drawings of patent US2015210346A1.

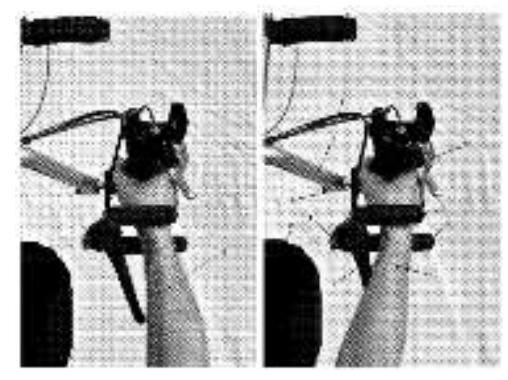

Source: Lofgren and Stewart (2014).

Van Galen (2014) proposed a lever driven handbike. Both the propulsion and the steering are performed by the movement of the lever: the propulsion is provided by moving back and forth, the steering, moving to the left and to the right. Fig. 11 presents some drawings of the invention. The patent has already expired.

Figure 11: Drawings of patent AU2014202010A1.
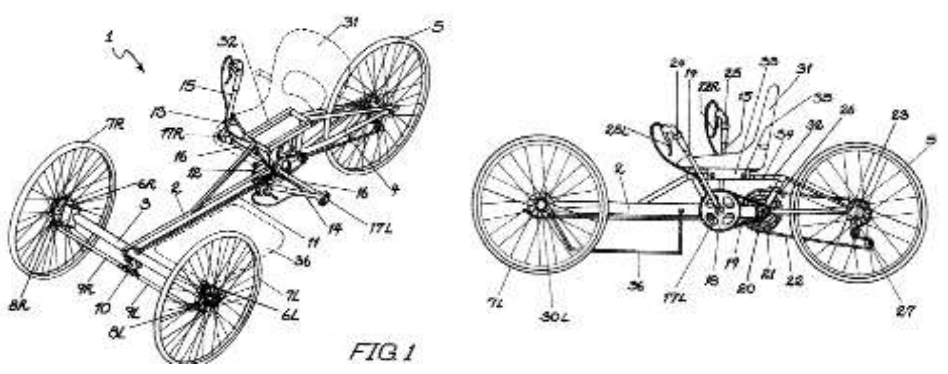

Source: van Galen (2014).

Kraiss (2016) created an independent crank system that can lock and unlock easily the arm crank to synchronous or asynchronous position. The system comprises two rings that, when one ring is held, the other can rotate freely in one direction, but a locking mechanism prevents that ring from rotating in the opposite direction. Figure 12 presents some drawings of the invention. The patent has been withdrawn. 
Figure 12: Drawings of patent DE102016001286A1.

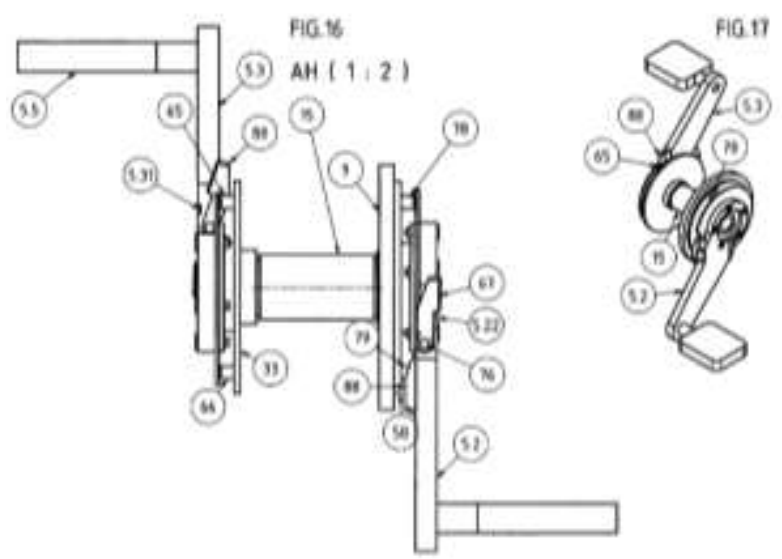

Source: Kraiss (2016).

Jong-bae et al. (2016) developed a hand cycle crank that can be adjusted according to the user body. The crank arm has a convex arch shape that, according the inventors, provides power more effectively using gravity force. Figure 13 presents some drawings of the invention. The patent is active.

Figure 13: Drawings of patent KR101899315B1.
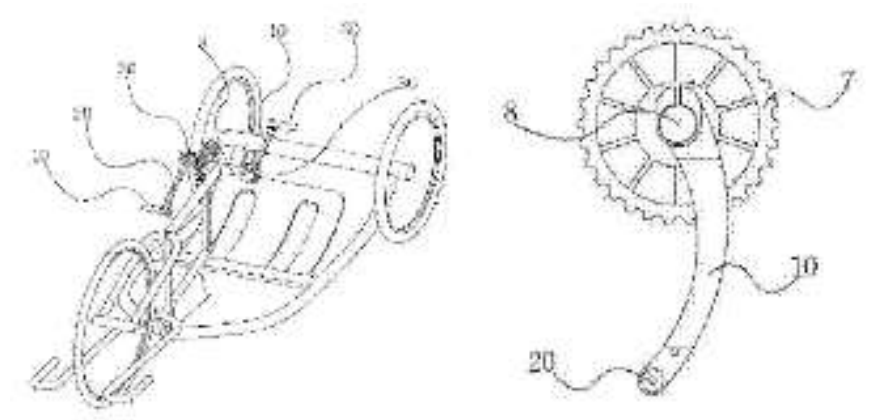

Source: Jong-bae et al. (2016).

Jin-Sung et al. (2016) developed a safety system for speed handibikes that minimizes air resistance and prevents the vehicle from overturning. The system comprises a front portion at the frame base, through which air enters, and the air discharge portion, at the bottom of the rear end. Figure 14 presents some drawings of the invention. The patent is active. 
Figure 14: Drawings of patent KR101800185B1.
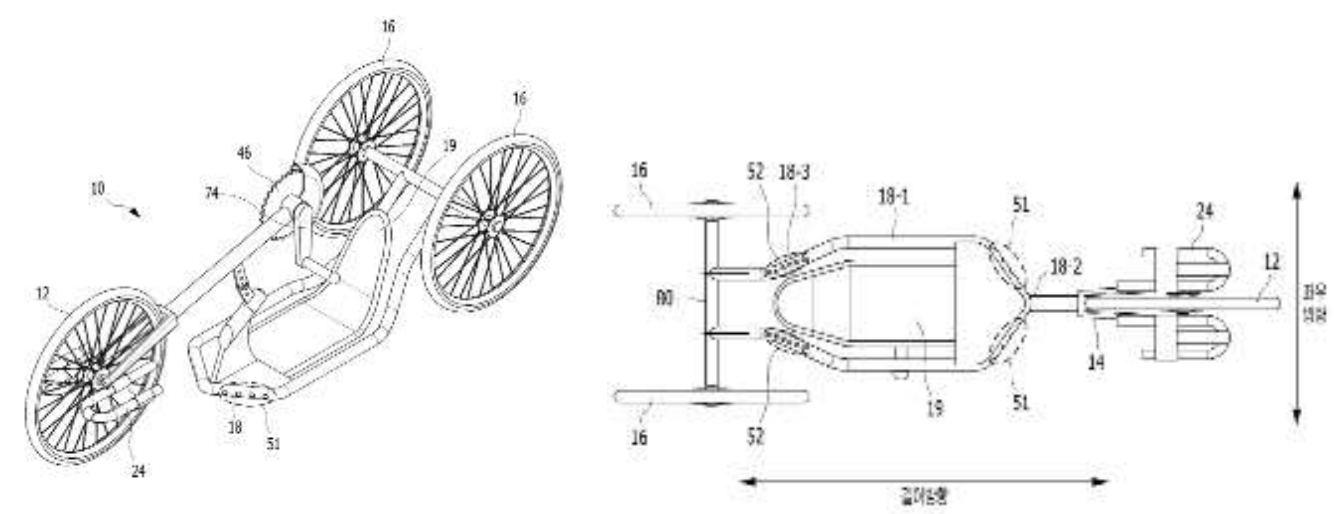

Source: Jin-Sung et al. (2016).

Kirschke and Fiedler (2019) designed a handbike with adjustable crank. The crank is mounted on a spring-loaded arm that can be rotated in relation to the vehicle's chassis. The articulated arm can be rotated to a maximum vertical position, which allows easy entry and exit, as shown in Figure 15. The patent is active.

Figure 15: Drawings of patent DE102019112850B3.
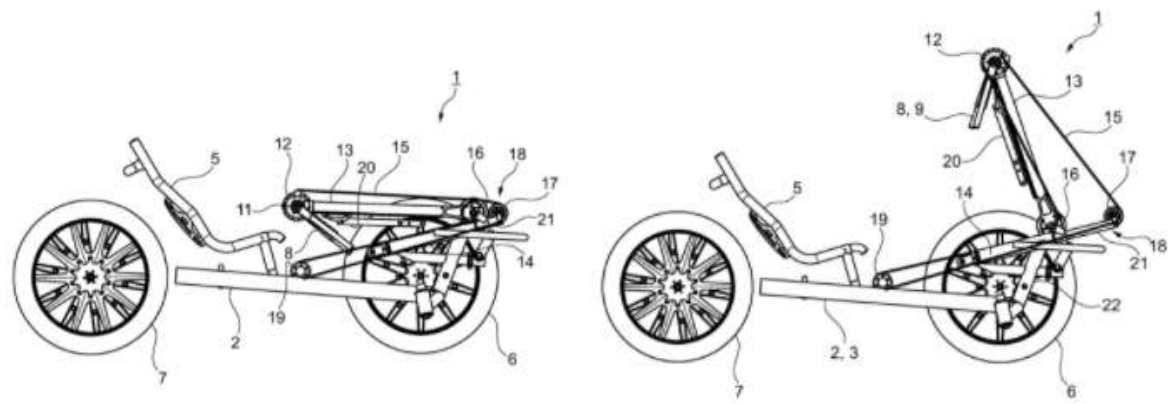

Source: Kirschke and Fiedler (2019).

\section{Conclusion}

In searches, the most commonly found terms were "handbike" and "handcycle" to name these vehicles. Something similar can be observed with the terms "bicycle" and "bike". Although in a smaller number, the terms "hand bike / hand-bike" "hand cycle / hand-cycle" are still related. Some research should be carry out to achieve what term is better to name the vehicle in Brazil.

The results of scientific articles about handbikes on searches platforms demonstrate that there are still few studies about the subject. The studies found can contribute to a better understanding of biomechanical and physiological parameters, important data for understanding the rider's body function during propulsion and how the applied force is transmitted to the vehicle. This knowledge is necessary because it is one of the variables in determining mechanical efficiency and the effectiveness of its performance determines a better user experience, without the risk of injury. The articles also provided component design parameters, such as dimensions and configurations, as well as component and vehicle concepts, which are essential for the development of handbikes, since, according to Litzenberger et al. (2015), "muscular effort is clearly influenced by the handcycle parameters". Technical parameters obtained through user requirements using the QFD technique and surveys indicate which the determining factors in the design of handbikes. Another contribution is in the formation of a 
Reference Bank (since the articles mentioned in the found papers were not identified in the search platforms) to future studies.

Although handbikes present higher mechanical efficiency and are considered less constraining than the hand-rim wheelchairs, according to Faupin et al. (2006), in submaximal propulsion, the angular amplitudes of the upper extremities joints were near from the values obtained with a hand-rim wheelchair, since speed has an influence on the force characteristics of handbike propulsion (Arnet, van Drongelen, et al., 2012). Then, the handbike design must considerer these factors to meet a better ride experience and avoid injuries.

As noted by Vaghetti et al. (2012), most handbikes in the country are developed by hand, rustic and with adapted parts, usually common bicycles, since there are no standards or regulations for handbikes design (Leal \& Silva, 2018). I.e., they are not developed based on technical criteria, without ergonomic or biomechanical studies. Thus, these vehicles (manufactured in these ways) may pose some danger to the user's integrity.

The results of patents about handbikes on search platform demonstrate that in the last 10 years the number has improved, although there are still few applications. This movement may be caused by the new polices and legislations around the world regarding the inclusion of people with disabilities. The applications presented some interesting concepts of handbikes and handbike components, such as the inventions developed by Dong-Woo and Yon-Seung (2014), Lofgren and Stewart (2014), Kraiss (2016) and Kirschke and Fiedler (2019). However, most of these records have been abandoned or have expired. As it can be noted, there are no patents in Brazil even finding some handbike models on the streets.

The studies that presented concepts of handbike did not mention whether that invention had been patented. The applications found did not mention any scientific studies related to presented invention.

Most of the patents found were related to subgroup B62M 1/14 of the IPC classification (although there are other subgroups that are also suitable for handbikes), representing about $30 \%$ of the result. This may represent products for purposes other than handbikes or misclassification (that may mean little knowledge about the created product by inventors). Thus, there may be other relevant inventions related to handbikes in other IPC classifications, scope for future studies.

According to Arnet et al. (2012) and Hettinga et al (2010), handbikes are a good means of daily transportation for people with lower-limb impairment. However, as Vaghetti et al. (2012) noted, they do not allow the possibility of access to indoor environments. Thus, the dependence on the conventional wheelchair still exists, as well as with all the disadvantages associated with this vehicle. Therefore, handbikes also present points of project improvement, perhaps still not observed by users due to the current concept proposal of these vehicles.

Realizing the relevance of the issues faced by people with motor disabilities, it is concluded that there is potential for working with handbikes in Brazil, since the research showed that there is a market gap.

For future work, the variation of the population of people with motor disabilities should be verified through updated statistical data, since the Census was not carried out in 2020. Other IPC classifications should be researched to prospect patented inventions in other subgroups.

\section{References}

Arnet, U., Van Drongelen, S., Van Der Woude, L. H. V., \& Veeger, D. H. E. J. (2012). Shoulder load during handcycling at different incline and speed conditions. Clinical Biomechanics, 27(1), 1-6. https://doi.org/10.1016/j.clinbiomech.2011.07.002

Arnet, U., van Drongelen, S., Veeger, D. J. H. E. J., \& van der Woude, L. H. V. (2012). Are the force characteristics of synchronous handcycling affected by speed and the method to impose power? Medical Engineering and Physics, 34(1), 78-84. https://doi.org/10.1016/j.medengphy.2011.07.001

Bailey, D., \& Hoepnner, K.(2011). Handcycle and drive machanism therefore. U.S. Patent Application No. US2012235377A1.

Biolchini, J., Mian, P. G., Natali, A. C. C., \& Travassos, G. H. (2005). Systematic Review in Software Engineering. Technical Report ES 679/05.

Briner, R. B., Denyer, \& D., Rousseau, D. M. (2009). Evidence-based management: Construct clean-up time? Academy of Management Perspectives, 23(4), $19-32$. 
Briner, R. B., \& Denyer, D. (2012). Systematic Review and Evidence Synthesis as a Practice and Scholarship Tool. The Oxford Handbook of Evidence-Based Management, November 2015. https://doi.org/10.1093/oxfordhb/9780199763986.013.0007

Caregnato, S. E. (2012). GOOGLE ACADÊMICO COMO FERRAMENTA PARA OS ESTUDOS DE CITAÇÕES: Avaliação da Precisão das Buscas por Autor. PontodeAcesso, 5(3), 72. https://doi.org/10.9771/1981-6766rpa.v5i3.5682

Carvalho-Freitas, M. N. de. (2007). a Inserção De Pessoas Com Deficiência Em Empresas Brasileiras - Um Estudo Sobre As Relações Entre Concepções De Deficiência, Condições De Trabalho E Qualidade De Vida No Trabalho. January, 1-315.

Carvalho-Freitas, M. N. de. (2009). Inserção e gestão do trabalho de pessoas com deficiência: um estudo de caso. Revista de Administração Contemporânea, 13(spe), 121-138. https://doi.org/10.1590/s1415-65552009000500009

Diniz, R., \& Ferro, L. (2016). Validação Projetual: Teste Preliminar De Usabilidade Em Um Protótipo De Um Handbike. December, 490-501. https://doi.org/10.5151/engpro-conaerg2016-7829

Dong-Woo, K., \& Yon-Seung, J. (2014). A Combined Hand Bike and Recumbent Bike. KR101693815B1.

Dos Santos Amparo, K. K., Do Ribeiro, M. C. O., \& Guarieiro, L. L. N. (2014). Estudo de caso utilizando mapeamento de prospecção tecnológica como principal ferramenta de busca científica. Perspectivas Em Ciencia Da Informacao, 17(4), 195-209. https://doi.org/10.1590/S1413-99362012000400012

Faupin, A., Gorce, P., Campillo, P., Thevenon, A., \& Rémy-Néris, O. (2006). Kinematic analysis of handbike propulsion in various gear ratios: Implications for joint pain. Clinical Biomechanics, 21(6), 560-566. https://doi.org/10.1016/j.clinbiomech.2006.01.001

Faupin, Arnaud, \& Gorce, P. (2008). The effects of crank adjustments on handbike propulsion: A kinematic model approach. International Journal of Industrial Ergonomics, 38(7-8), 577-583. https://doi.org/10.1016/j.ergon.2008.01.019

Franks, J., \&Tim, B. (1997). Handcycle. U.S. Patent Application No. US6105986A.

Goosey-Tolfrey, V. (2010). Wheelchair Sport.

Himarosa, R. A., \& Sunardi. (2020). Design, Frame Analysis and Manufacture of Handcycle Prototype. Journal of Physics: Conference Series, 1471(1). https://doi.org/10.1088/1742-6596/1471/1/012058

Hrdlicka, F. (2015). Terénní handbike.

IBGE - Intituto Brasileiro de Geografia e Estatística. (2012). Censo Brasileiro de 2010.

INPI - Intituto Nacional da Propriedade Industrial. (2020). Classificação de Patentes. http://www.inpi.gov.br/menu-servicos/patente/classificacao-de-patentes.

Jeang, A., Liang, F., \& Huang, H. F. (2015). Handcycle design \& development process for the disabled. 2015 IFToMM World Congress Proceedings, IFToMM 2015, 96-104. https://doi.org/10.6567/IFToMM.14TH.WC.PS3.002

Jin-Man, C. (2007). Wheelchair Handcycle Kit. KR100886325B1.

Jin-Sung . K., Jong- Bae, K., \& Min-Ho, Y. (2016). Handcycle. KR101800185B1.

Jong- Bae, K., Jin-Sung, K., \& Young-Ju, L. (2016). Hand cycle crank. KR101899315B1.

Kirschke, P., \& Fiedler, T. (2019). Handbike. DE102019112850B3. Deutsches Patent und Markenamt.

Kitchenham, B. (2004). Procedures for performing systematic reviews. Keele.

Kraiss, M. (2016). Fahrrad oder Heimtrainer mit Arm- und oder Beinantrieb. DE102016001286A1. Deutsches Patent und Markenamt.

Kyncl, Z. (2011). Handbike do lehkého terénu.

Lasher, W.J., III. (2012). Stabilizing Device and Method for Handcycle. U.S. Patent Application No. US2014167383A1.

Lasher, W.J., III. (2013). Suspension for Handcycle. U.S. Patent Application No. US2014239610A1.

Leal, L. E. A. M., \& Silva, R. R. (2018). Desenvolvimento de uma Handbike de baixo custo. Inovação \& Propriedade Intelectual.

Lee, D. (1998). Modified prone handcycle. U.S. Patent Application No. US6036210A.

Litzenberger, S., Mally, F., \& Sabo, A. (2015). Influence of different seating and crank positions on muscular activity in elite handcycling - A case study. Procedia Engineering, 112, 355-360. https://doi.org/10.1016/j.proeng.2015.07.262

Lofgren, M. S., \& Stewart, B.C. (2014). Arm Actuated Brake Lever for Quadriplegic. U.S. Patent Application No. US2015210346A1.

Maries, N. D. (2019). Progettazione di handcycle da record di velocità.

Matvijová, P. (2017). Konstrukčni návrh volnočasového vozíku typu handbike.

Mayerhoff, Z. D. V. L. (2008). Uma Análise Sobre os Estudos de Prospecção Tecnológica. Cadernos de Prospecção, 1(1), 3. 
Research, Society and Development, v. 10, n. 6, e3810615342, 2021

(CC BY 4.0) | ISSN 2525-3409 | DOI: http://dx.doi.org/10.33448/rsd-v10i6.15342

http://www.portalseer.ufba.br/index.php/nit/article/view/3538/2637\%0Ahttp://ic.ufal.br/evento/cbie_laclo2015/eventos.html\%0Ahttps://portalseer.ufba.br/inde x.php/nit/article/view/23039

Moreno, Á. P. (2019). Diseño de los mecanismos de accionamiento de una silla de ruedas con handbike. 94.

Okoli, C. (2015). A guide to conducting a standalone systematic literature review. Communications of the Association for Information Systems, 37(1), 879910. https://doi.org/10.17705/1 cais.03743

Ortolan, R. L., Cunha, F. L. da, Carvalho, D. C. L. de, Franca, J. E. M., Maria, A. S. L. S., Silva, O. L., \& Cliquet Jr, A. (2001). Tendências em biomecânica ortopédica aplicadas à reabilitação. Acta Ortopédica Brasileira, 9(3), 44-58. https://doi.org/10.1590/s1413-78522001000300007

Pedro, F. J. D. (2019). Avaliação de complexos eólicos através do método de decisão multicritério TOPSIS.

Peterson, C.J. (2002). Extendable Handcycle pedal. U.S. Patent Application No. US2003075002A1.

Pires, E. A., Ribeiro, N. M., \& Quintella, C. M. (2020). Sistemas de Busca de Patentes: análise comparativa entre Espacenet, Patentscope, Google Patents, Lens, Derwent Innovation Index e Orbit Intelligence. Cadernos de Prospecção, 13(1), 13-29.

Ribeiro, M.C.O., \& Alves, F.M.M. (2020). Prospecting Studies on the scientific and technological production of SARS-COV-2. Revista Fontes Documentais. Rotz, C., Nielson, S., Musso, C., Horito, M. (2001). Handcycle. U.S. Patent Application No. US2002030342A1.

Sampaio, R., \& Mancini, M. (2007). Systematic Review Studies: a Guide for Careful Synthesis of Scientific Evidence. Rev. Bras. Fisioter, 11(1), 77-82.

Santos, M. de M., Coelho, G. M., Santos, D. M. dos, \& Fellows Filho, L. (2004). Prospecção de tecnologias de futuro: métodos, técnicas e abordagens. Parcerias Estratégicas, 9(19), 189-230.

Sato, C. (2010). Two-weeled drive hand cycle. JP2012071728A.

Sato, C. (2013). Ratchet type hand cycle. JP2013233841A.

Seo, H. W., Kim, D. D., Ko, C. W., Lee, J. H., \& Bae, T. S. (2015). Structural Stability Analysis of Connectors for an Electric Handbike. Journal of the Korean Society for Precision Engineering, 32(5), 491-496. https://doi.org/10.7736/kspe.2015.32.5.491

Stone, B. (2019). Recumbent Handbike Set-up for Sports Performance. Loughborough University. https://doi.org/10.26174/thesis.lboro.10565795.v1.

Tober, M. (2011). PubMed, ScienceDirect, Scopus or Google Scholar - Which is the best search engine for an effective literature research in laser medicine? Medical Laser Application, 26(3), 139-144. https://doi.org/10.1016/j.mla.2011.05.006

Vaghette, C. A. O., Mederiros, M. A., \& Witt, L. R. (2012). Aspectos Biomecânicos entre usuários da cadeira de rodas Handcycle e convencional. Cinergis.

Van Drongelen, S., van den Berg, J., Arnet, U., Veeger, D. J., \& van der Woude, L. H. V. (2011). Development and validity of an instrumented handbike: Initial results of propulsion kinetics. Medical Engineering and Physics, 33(9), 1167-1173. https://doi.org/10.1016/j.medengphy.2011.04.018

van Galen, D. G. (2014). Lever Driven Handcycle. Standard Patent Application No. AU2014202010A1. Australian Patent Office.

Verellen, J., Meyer, C., Reynders, S., Van Biesen, D., \& Vanlandewijck, Y. (2008). Consistency of within-cycle torque distribution pattern in hand cycling. Journal of Rehabilitation Research and Development, 45(9), 1295-1302. https://doi.org/10.1682/JRRD.2007.12.0205

Verellen, J., Theisen, D., \& Vanlandewijck, Y. (2004). Influence of crank rate in hand cycling. Medicine and Science in Sports and Exercise, 36(10), 18261831. https://doi.org/10.1249/01.MSS.0000142367.04918.5A

WIPO - World Intellectual Property Organization. (2020). Guide to the International Patent Classification. 